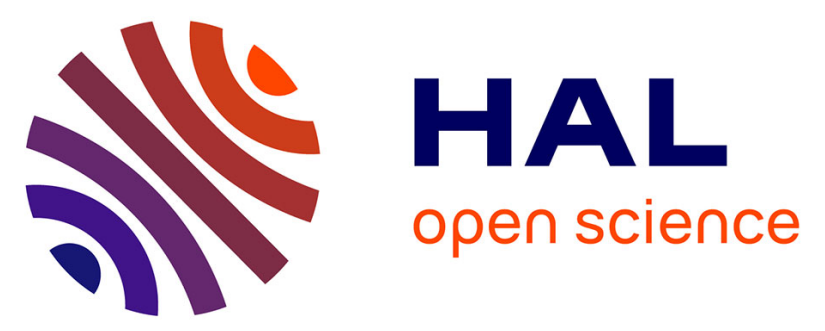

\title{
Bioclimate influence on seed germination and seedling morphology parameters in Pterocarpus erinaceus Poir., 1804 (Fabaceae)
}

Beda Innocent Adji, Sélastique Doffou Akaffou, Kouadio Henri Kouassi, Yao

Patrice Houphouet, Jérôme Duminil, Sylvie-Annabel Sabatier

\section{To cite this version:}

Beda Innocent Adji, Sélastique Doffou Akaffou, Kouadio Henri Kouassi, Yao Patrice Houphouet, Jérôme Duminil, et al.. Bioclimate influence on seed germination and seedling morphology parameters in Pterocarpus erinaceus Poir., 1804 (Fabaceae). International Journal of Environment, Agriculture and Biotechnology, 2021, 6 (3), pp.001-015. 10.22161/ijeab . hal-03227802

\section{HAL Id: hal-03227802 \\ https://hal.inrae.fr/hal-03227802}

Submitted on 29 Jul 2021

HAL is a multi-disciplinary open access archive for the deposit and dissemination of scientific research documents, whether they are published or not. The documents may come from teaching and research institutions in France or abroad, or from public or private research centers.
L'archive ouverte pluridisciplinaire $\mathbf{H A L}$, est destinée au dépôt et à la diffusion de documents scientifiques de niveau recherche, publiés ou non, émanant des établissements d'enseignement et de recherche français ou étrangers, des laboratoires publics ou privés. 


International Journal of Environment, Agriculture and Biotechnology
Vol-6, Issue-3; May-Jun, 2021
J Journal Home Page Available: https://ijeab.com/
Journal DOI: $10.22161 /$ ijeab

\title{
Bioclimate influence on seed germination and seedling
} morphology parameters in Pterocarpus erinaceus Poir., 1804 (Fabaceae)

\author{
Beda Innocent Adji ${ }^{1,2}$, Doffou Sélastique Akaffou ${ }^{1}$, Kouadio Henri Kouassi ${ }^{1}$, Yao \\ Patrice Houphouet ${ }^{1}$, Jerôme Duminil ${ }^{3}$, Sylvie Annabel Sabatier ${ }^{2}$
}

\begin{abstract}
${ }^{1}$ Université Jean Lorougnon Guédé, Agroforestry UFR, BP 150, Daloa, Côte d'Ivoire
${ }^{2}$ CIRAD, UMR AMAP, F-34398 Montpellier, France ; AMAP, Université Montpellier, CIRAD, CNRS, INRA, IRD, Montpellier, France ${ }^{3}$ IRD, UMR-DIADE, Montpellier Cedex 5, France ; DIADE, Université Montpellier, CIRAD, IRD, Montpellier, France *Corresponding Author: adjibedainnocent@gmail.com/beda-innocent.adji@cirad.fr
\end{abstract}

Received: 01 Feb 2021; Received in revised form: 20 Mar 2021; Accepted: 19 Apr 2021; Available online: 09 May 2021 (C)2021 The Author(s). Published by Infogain Publication. This is an open access article under the CC BY license (https://creativecommons.org/licenses/by/4.0/).

\begin{abstract}
Pterocarpus erinaceus is over-exploited for its multiple uses. Its exploitation and trade are strictly prohibited in many countries, including Côte d'Ivoire, to prevent its extinction. It is nevertheless imperative to restore populations of this species, while accounting for its germinative capacities and its adaptation to changing climates. The aim of this study was to assess the seed germination and seedling development in Pterocarpus erinaceus in three different environments. A total of 2,160 seeds from different seed trees and 540 individuals germinated from seeds were selected and evaluated. The trials were conducted at three sites with distinct microclimates (two nurseries in Côte d'Ivoire and one greenhouse in France). The results showed that the environment had a significant influence on germination parameters $(P<0.05)$, whereas the seed trees did not $(P>0.05)$. The environment influenced the height and internodes length of the seedlings $(P<0.05)$. However, the diameter, number of leaves, and the length and width of the leaves of the seedlings were statistically identical from one site to another $(P>0.05)$. Seed trees influenced the number and length of seedlings leaves $(P<0.05)$. PCA showed that the seedlings developed better in the Montpellier greenhouse and at the Daloa site than Korhogo site. This information could guide the choice of ideal environments for the implementation of reforestation or agroforestry programs based on Pterocarpus erinaceus in the current context of climate change from a nursery. This study could be extended to other species in order to regenerate important species in disturbed ecosystems.
\end{abstract}

Keywords- Pterocarpus erinaceus, nurseries, greenhouse, environment, germination and seedling morphology, Côte d'Ivoire.

\section{INTRODUCTION}

Plant genetic resources, a component of biodiversity, the biological basis of the planet's environmental equilibrium, and a source of economic and ecological security for the future, provide the basis for sustainable development (Houndonougbo et al. 2020; Choat et al. 2012; United Nation 2002). Today, this biodiversity is threatened by overexploitation, yet the survival of all humanity depends on it. In 1992 in Rio de Janeiro, the United Nations adopted the following authoritative but not legally binding declaration: "Forest resources and woodlands should be managed on a sustainable basis in order to meet the social, economic, ecological, cultural and spiritual needs of present and future generations". These needs relate to the products and services that the forest can provide such as wood and wood-based products, water, food, fodder, medicinal products, fuel, shelter, employment, recreation, wildlife habitat, a source of diversity in the landscape, the role of a carbon sink and reservoir, and many other products from the forest. Appropriate measures should be taken to protect forests from the damaging effects (Leroy 2015). 
In Africa, forest degradation is intensifying because the principles of sustainable forest management are being ignored (Rabiou et al. 2015; Dipelet et al. 2019). Targeted and selective exploitation of certain important forest species severely threatens the forest ecosystems of many West African countries (Segla et al. 2016, 2020; Mbowa et al. 2013). To respond effectively to the current environmental emergency, sustainable forest management must therefore become an integral part of farmers' usual agricultural practices. Regenerating the forest and/or reconciling forest with modern agriculture by associating important forest tree species (leguminous, food, fodder, and medicinal species) with crops is a choice and a major challenge that many African countries including Côte d'Ivoire want to take up $($ Reed +2017$)$.

Generally, trees are markers of the identity of the rural populations that use them in West Africa (Mabetty 2018). Among these trees, Pterocapus erinaceus., Poir (1804) from Fabaceae family called veneer wood «bois de vène » or Senegal rosewood is a spontaneous, forest fire-resistant, nitrogen-fixing CITES species and is native to fragile semiarid habitats (CITES 2016; Anonymous 2016; Dumenu 2019). She originates from the Guinean-Sudanian and Sudano-Sahelian zones of West Africa and is highly overexploited for its multiple uses (quality timber, fodder, medicine, dyeing, soil restoration, etc.) (Ouedraogo et al. 2006; Rabiou et al. 2019; Goba et al. 2019; Segla et al. 2020). Indeed, recent years have been characterized by a spectacular increase in the trade of Pterocarpus erinaceus. This increase responds on the one hand to the growing demand for rosewood furniture in Asia, and on the other hand to the increasing scarcity of other species officially recognized as "rosewood" (several are listed in the CITES Appendices). It is estimated that exports of Pterocarpus erinaceus as $\log$ s to China increased by a factor of 2,000 between the third quarter of 2009 and the third quarter of 2015, from $70 \mathrm{~m}^{3}$ to over $149,000 \mathrm{~m}^{3}$ (Cop 17 2016). Widespread illegal and unsustainable exploitation of the species within its range has led many States of West Africa (i.e. Burkina Faso, Benin, Togo, Niger, Côte d'Ivoire) to enact total bans on harvesting and trade in the species in recent years, with the aim of preventing its extinction.

In Côte d'Ivoire, the exploitation of Pterocarpus erinaceus is prohibited by decree $\mathrm{n}^{\circ} 2013-508$ of 25 July 2013 (MINEF 2013). Despite these measures, its trade continues to grow steadily so that Pterocarpus erinaceus stands are almost non-existent in Côte d'Ivoire today. Given the importance of this species and faced with this problem, which could lead to a loss of diversity that could lead to its extinction in Côte d'Ivoire, there is an urgent need to develop strategies for the rapid regeneration of this species.

Among several rapid regeneration solutions, domestication through germination tests has proved to be very effective in saving pioneer species that are threatened or overexploited in many countries (Amani et al. 2015; Douma et al. 2019; Adji et al. 2020). However, in the current context of climate change for the domestication of Pterocarpus erinaceus, several questions arise: (i) could the ever-changing environment have an effect on seed germination? (ii) are the dendrometric characteristics of the seed tree (ideal choice of seed trees) necessary to obtain a good germination rate? (iii) is the choice of vigorous seedlings resistant to climatic stress necessary? (iv) do seedlings of this species adapt to different types of environment? (v) is seedling development influenced by the type of seed tree? (vi) could the germination or morphology parameters of the seedlings guide the choice of an environment conducive to the implementation of a forest or agroforestry management programme? etc. This study was carried out with the aim of trying to answer all these questions. The objective is to evaluate the germination of seeds and the development of Pterocarpus erinaceus seedlings in a changing environment.

\section{MATERIAL AND METHODS}

\subsection{Plant material}

The plant material is composed of seeds obtained after shelling of mature fruits, from six seed trees growing more than $300 \mathrm{~m}$ apart in the same stand of Pterocarpus erinaceus and four-months old seedlings resulting from the germination of seeds collected under the six seed trees. All the seeds were collected from trees in good physiological condition in April 2019 at the experimental station (DeFo) of the CNRA (Centre National de Recherche Agronomique) in the Korhogo department of Côte d'Ivoire. The characteristics of the seed trees are listed in Table 1. The plant material used is the property of the CNRA of Côte d'Ivoire and the authorisation to use this plant material was given to us in the framework of this study via a partnership agreement signed and available on request between the said structure and our study project (EFISA). The formal identification of the species was undertaken by Poir in 1804 (Encycl.5 728.1804) (Anonymous 2019). A specimen of this material exists in the public herbarium ( $\left.\mathrm{N}^{\circ} \mathrm{UCJ} 010935\right)$ of the CSRS (Centre Suisse de Recherches Scientifiques) in Côte d'Ivoire (Bakayoko et al. 2020) and the CNF (Centre National de Floristique) in Côte d'Ivoire (Koffi et al. 2018).

Table 1 Characteristics of Pterocarpus erinaceus seed trees and seeds used 


\begin{tabular}{|c|c|c|c|c|c|c|c|c|c|}
\hline \multirow{2}{*}{$\begin{array}{l}\text { Seed } \\
\text { trees }\end{array}$} & \multirow{2}{*}{$\begin{array}{l}\text { DBH } \\
(\mathrm{cm})\end{array}$} & \multirow{2}{*}{$\begin{array}{c}\mathbf{H} \\
(\mathbf{m})\end{array}$} & \multirow{2}{*}{$\begin{array}{c}\text { Age } \\
\text { (year) }\end{array}$} & \multicolumn{2}{|c|}{ GPS coordinates } & \multirow{2}{*}{$\begin{array}{l}\text { Number } \\
\text { of seeds }\end{array}$} & \multicolumn{3}{|c|}{ Seed mass (g) } \\
\hline & & & & Longitude & Latitude & & Mini & Maxi & Mean \\
\hline 1 & 24.36 & 15 & 23 & $-5.55112 \mathrm{~W}$ & $9.5681 \mathrm{~N}$ & 360 & 0.02 & 0.1 & $0.07 \pm 0.01 \mathbf{a}$ \\
\hline 2 & 32.32 & 18.5 & 26 & $-5.55119 \mathrm{~W}$ & $9.56797 \mathrm{~N}$ & 360 & 0.06 & 0.1 & $0.08 \pm 0.01 \mathbf{a}$ \\
\hline 3 & 31.05 & 18 & 26 & $-5.55134 \mathrm{~W}$ & $9.56779 \mathrm{~N}$ & 360 & 0.04 & 0.08 & $0.07 \pm 0.01 \mathbf{a}$ \\
\hline 4 & 26.11 & 15.5 & 22 & $-5.55122 \mathrm{~W}$ & $9.56785 \mathrm{~N}$ & 360 & 0.04 & 0.1 & $0.07 \pm 0.01 \mathbf{a}$ \\
\hline 5 & 29.78 & 16.5 & 25 & $-5.55132 \mathrm{~W}$ & $9.56781 \mathrm{~N}$ & 360 & 0.05 & 0.1 & $0.07 \pm 0.01 \mathbf{a}$ \\
\hline 6 & 23.88 & 16.5 & 25 & $-5.55131 \mathrm{~W}$ & $9.56808 \mathrm{~N}$ & 360 & 0.02 & 0.1 & $0.070 .02 \mathbf{a}$ \\
\hline
\end{tabular}

DBH = Diameter at chest height in centimetres; $\mathbf{H}=$ Height in metres; $\mathbf{W}=$ West; $\mathbf{N}=$ North; $\mathbf{M i n i}=$ Minimum in grams; Maxi = Maximum in grams

\subsection{Methods}

\subsubsection{Study sites}

The trials were implemented April to September 2019 in three sites, two in Côte d'Ivoire and one in France with different microclimates. Of the two sites in Côte d'Ivoire, one was at the CNRA forest experimental station (hereafter DeFo) in Korhogo, and the other at the Université Jean
Lorougnon Guédé (hereafter UJLoG), in Daloa. The trial in France took place in a controlled environment, in Greenhouse 8 at CIRAD (The French agricultural research and international cooperation organization working for the sustainable development of tropical and Mediterranean regions) in Montpellier. The characteristics of the study sites are listed in Table 2.

Table 2 Geographical location and characteristics of study sites (Guillaumet and Adjanohoun 1971; Perraud 1971; Loupe and Ouattara 1996; Bornand et al. 1999; FAO 2005; Goula et al. 2007; Soro 2011; Djaha et al. 2012; Millan 2016; Barry et al. 2018; AISA 2019; Anonymous 2019; Hérault et al. 2020).

\begin{tabular}{|c|c|c|c|c|c|c|}
\hline $\begin{array}{l}\text { Study sites } \\
\text { or } \\
\text { Bioclimates }\end{array}$ & Coordinates & Vegetation & Climate & Temperature & $\begin{array}{c}\text { Rainfall } \\
\text { (mm/year) }\end{array}$ & Soil type \\
\hline $\begin{array}{l}\text { Korhogo } \\
\text { (DeFo) }\end{array}$ & $\begin{array}{l}9^{\circ} 5700^{\prime} 80556^{\prime \prime} \mathrm{N} \\
5^{\circ} 542^{\prime} 88889^{\prime \prime} \mathrm{W}\end{array}$ & $\begin{array}{l}\text { Clear forest } \\
\text { (wooded } \\
\text { and grassy } \\
\text { savannah) }\end{array}$ & $\begin{array}{c}\text { Tropical } \\
\text { dry }\end{array}$ & $26.6-35.7^{\circ} \mathrm{C}$ & $817-1216$ & $\begin{array}{l}\text { Ferruginous }(90 \%) \text { and } \\
\text { Ferralitic }(10 \%) \\
\text { superficial gravelly soil, } \\
\text { deep gravel with a } \\
\text { heavy texture, low in } \\
\text { organic matter, highly } \\
\text { desaturated. }\end{array}$ \\
\hline $\begin{array}{c}\text { Daloa } \\
\text { (UJLoG) }\end{array}$ & $\begin{array}{l}6^{\circ} 909^{\prime} 6363^{\prime \prime} \mathrm{N} \\
6^{\circ} 438^{\prime} 1157^{\prime \prime} \mathrm{W}\end{array}$ & $\begin{array}{l}\text { Dense rain } \\
\text { forest }\end{array}$ & $\begin{array}{c}\text { Wet } \\
\text { tropical } \\
\text { (sub- } \\
\text { equatorial) }\end{array}$ & $21-34{ }^{\circ} \mathrm{C}$ & $1000-1900$ & $\begin{array}{l}\text { Ferralitic, deep, acidic } \\
\text { and desaturated in } \\
\text { exchangeable bases, } \\
\text { rich in organic matter }\end{array}$ \\
\hline $\begin{array}{c}\text { Montpellier } \\
\text { (Greenhous } \\
\text { e) }\end{array}$ & $\begin{array}{l}43^{\circ} 64981^{\prime} \mathrm{N} \\
3^{\circ} 86842^{\prime} \mathrm{W}\end{array}$ & $\begin{array}{l}\text { in the } \\
\text { greenhouse }\end{array}$ & $\begin{array}{c}\text { in the } \\
\text { greenhous } \\
\mathrm{e}\end{array}$ & $\begin{array}{c}24{ }^{\circ} \mathrm{C} \text { (night) } \\
- \\
32{ }^{\circ} \mathrm{C} \text { (day) }\end{array}$ & $\begin{array}{l}10 \mathrm{~cm}^{3} \text { per } \\
\text { week for } \\
\text { each pot }\end{array}$ & $\begin{array}{c}\text { Mixture of Substrate } \\
\text { Soil 1, Neuhaus N2 Bio, } \\
\text { Tref Rice CIRAD } 2 \text { and } \\
\text { extra-silica sand from } \\
\text { bio }\end{array}$ \\
\hline
\end{tabular}

$\overline{\mathbf{W}}=$ West $\mathbf{N}=$ North $;{ }^{\circ} \mathbf{C}=$ degrees Celsius; $\mathbf{m m}=$ millimetre; Substrate $\mathbf{1}=$ Iron, trace elements, perlite and coconut fibre; Neuhaus N2 Bio = vegetable co-composting, blond and black peat; Tref Rice CIRAD 2 = clay, volcanic sand, perlite no. 2 , coconut, Irish white peat and fine blond peat
2.2.2. $\quad$ Setting up the tests
Seed harvesting 
Mature fruits were harvested in April and May 2019 on the seed trees using long wooden sticks with forks attached or by knocking the top of the tree with stones. The mature fruit collected under each seed tree was husked by hand to remove the thorny shells from the seeds. The seeds were then divided into three batches. Each batch contained seeds from all six seed trees (seed trees), i.e. 120 healthy seeds were selected per seed tree and per study site after sorting all the seeds collected ( 120 seeds x 6 seed trees $\mathrm{x} 3$ test sites giving a total of 2,160 seeds of Pterocarpus erinaceus).

\subsubsection{Test preparation and apparatus}

Site 1 and 2: Korhogo and Daloa Nursery

Polyethylene black bags with drainage holes measuring 20 $\mathrm{x} 10 \mathrm{~cm}$ were filled with local soil and arranged in one block comprising six sub-blocks. Each sub-block was labelled with the seed tree's serial number and geographic coordinates and contained seeds harvested on and under one seed tree. Each sub-block contained 60 bags of soil prepared to receive two seeds each. The seeds from each seed tree were soaked in water for 12 hours to break seed dormancy and then sowed directly at a depth of approximately $2 \mathrm{~cm}$ in the bags at a rate of two seeds per bag. Before planting, the seeds were treated with granulated FURADAN to control rodents and after seedling emergence, the pre-leaves were treated with DECIS to limit insects' attacks. Nursery maintenance consisted of daily watering and manual weeding.

\section{Site 3: Greenhouse at CIRAD, Montpellier}

Polyester black pots with drainage holes measuring $30 \times 15$ $\mathrm{cm}$ were filled with a mixture of potting compost as specified above (Table 2). The pots were arranged in labelled blocks and sub-blocks in metal bins arranged in the same way as in Korhogo and Daloa. The seeds were sown in the same way as those from the other two sites in Côte d'Ivoire. Biological protection consisted of treatment with BIOBEST against greenhouse whiteflies. The pots were watered daily $\left(10 \mathrm{~cm}^{3}\right.$ per week). all the pots occupied an area of about $12 \mathrm{~m}^{2}$.

\subsubsection{Data Collection}

\section{Germination parameters}

Five parameters were evaluated:

- Latency time, i.e. the time it takes for the first seed to germinate from the sowing of all the seeds (Amani et al. 2015);

- Germination delay refers to the period between the sowing of each seed and the appearance of each seedling (N'golo et al. 2018);
- Germination speed, i.e. the average time after which 50\% of the seeds have germinated (Berka and Abdelkader 2001; Diatta et al. 2009; Douma et al. 2019);

- Germination duration or Spread time, i.e. is the period between germination of the first seed and the last seed (Adji et al. 2020);

- Germination rate, i.e. the number of seeds sprouted divided by the number of total seeds sprouted, expressed as a percentage (Zerbo et al. 2010; Gorgon et al. 2015; Akaffou et al. 2019).

Development parameters

Six parameters were evaluated (Adji et al. 2020):

- Seedling height (SH), i.e. the length between the collar and the apex of the seedling;

- Diameter at the collar of seedling (Dcol), i.e. the base thickness of the main stem of the seedling;

- Number of leaves $\left(\mathrm{LN}^{\circ}\right)$ corresponds to the number of leaves on the main stem of the seedling;

-Leaf length (LL) corresponds to the length from the beginning of the petiole to the end of the main vein of the leaf blade of each leaf present on the main stem of the seedling;

-Leaf width (LW) corresponds to the width of the leaf blade or to the line perpendicular to the main vein in the centre of the leaf blade;

- Length of the internodes (LIN), i.e. the length connecting two nodes or the length of two points of successive insertions of organs or leaf scars, from the base to the apex of the seedling.

All morphological parameters were measured using a ruler graduated in centimeters and an electronic caliper in millimeters.

\subsubsection{Data analysis}

Statistical analyses were first performed using onedimensional descriptive statistics, link analysis (linear regression, correlation and covariance) and multidimensional analysis (principal component analysis, PCA) with XLSTAT 2020 version 7.5. The difference between the germination and development parameters was assessed using a two-factor multivariate analysis (MANOVA) with SAS software version 9.4. The StudentNewman-Keuls test at the $5 \%$ threshold was used for posthoc comparisons.

\section{RESULTS}

Pterocarpus erinaceus is epigerminated with a hypocotyl remaining in the soil, the epicotyl is on average $8.74 \mathrm{~cm}$ long and $1.8 \mathrm{~mm}$ in diameter at the base (at an of average 9 
days after sowing). The pre-leaves (at an average 10 days after sowing) have a long petiole in the same direction as the stem with two (2) stipules each at the base of the leaf sheath. The cotyledonary leaves remain visible for an average of 58 days. The phyllotaxis is alternate spiral with simple leaves with stipules until an average of 84 days, after which the seedling develops compound-imparipinnate and then compound-paripinnate leaves later (100 days on average). Branching appears on a few seedlings after the appearance of compound leaves (average 118 days).

3.1. Germination and development parameters by each study site

\subsubsection{Germination parameters \\ Site 1: Korhogo}

At the Korhogo site, the shortest germination latency was three days and was obtained with the seeds of seed trees 3, 5 and 6 (Fig 1a). The shortest germination delay ranged from four to 13 days to $6.17 \pm 2.249$ days, they were recorded in the seeds of seed tree 1 (Fig 1a). The seeds of seed trees 1 and 3 showed the fastest speed after nine days (Fig 1a). The shortest germination time was observed in the seeds of seed trees 1 and 2 with a duration of nine days (Fig 1a). The seeds of seed tree 6 had the highest germination rate with a rate of $86.66 \%$ (Fig $1 \mathrm{~b}$ ).

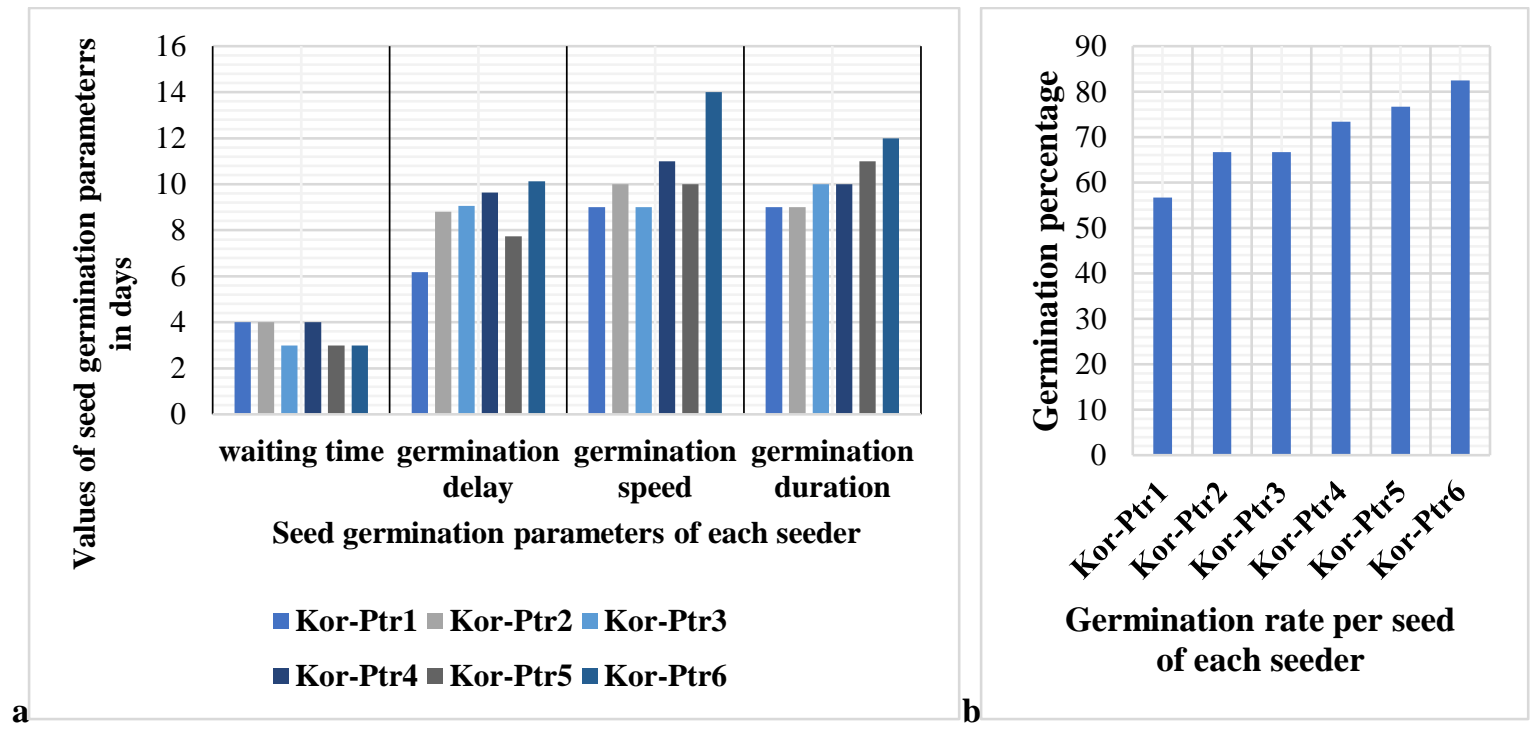

Kor-Ptr1=Seeds from seed tree 1, Kor-Ptr2=Seeds from seed tree 2, Kor-Ptr3=Seeds from seed tree 3, Kor-Ptr4=Seeds from seed tree 4, Kor-Ptr5=Seeds from seed tree 5, Kor-Ptr6=Seeds from seed tree 6

Fig 1. Distribution of seed germination parameters (a: Waiting time, germination delay, germination speed and germination duration; $b$ : germination rate) of the six seed trees in Korhogo nursery

Site 2: Daloa

At Daloa site, the seeds of seed trees 1, 5 and 6 were characterized by short latencies, i.e., a period of three days (Fig 2a). The germination delays of the seeds of seed tree 1 were minimal ranging, from three to 12 days with an average of $6.357 \pm 1.985$ days (Fig $2 \mathrm{a}$ ). The seeds of seed trees 1 and 2 had the highest germination rate after six days (Fig 2a). The range of germination was smaller in the seeds of seed trees 2, 4 and 5 at 7 days (Fig 2a. Seeds of seed tree 5 had the highest germination rate at $96.66 \%$ (Fig 2b). 


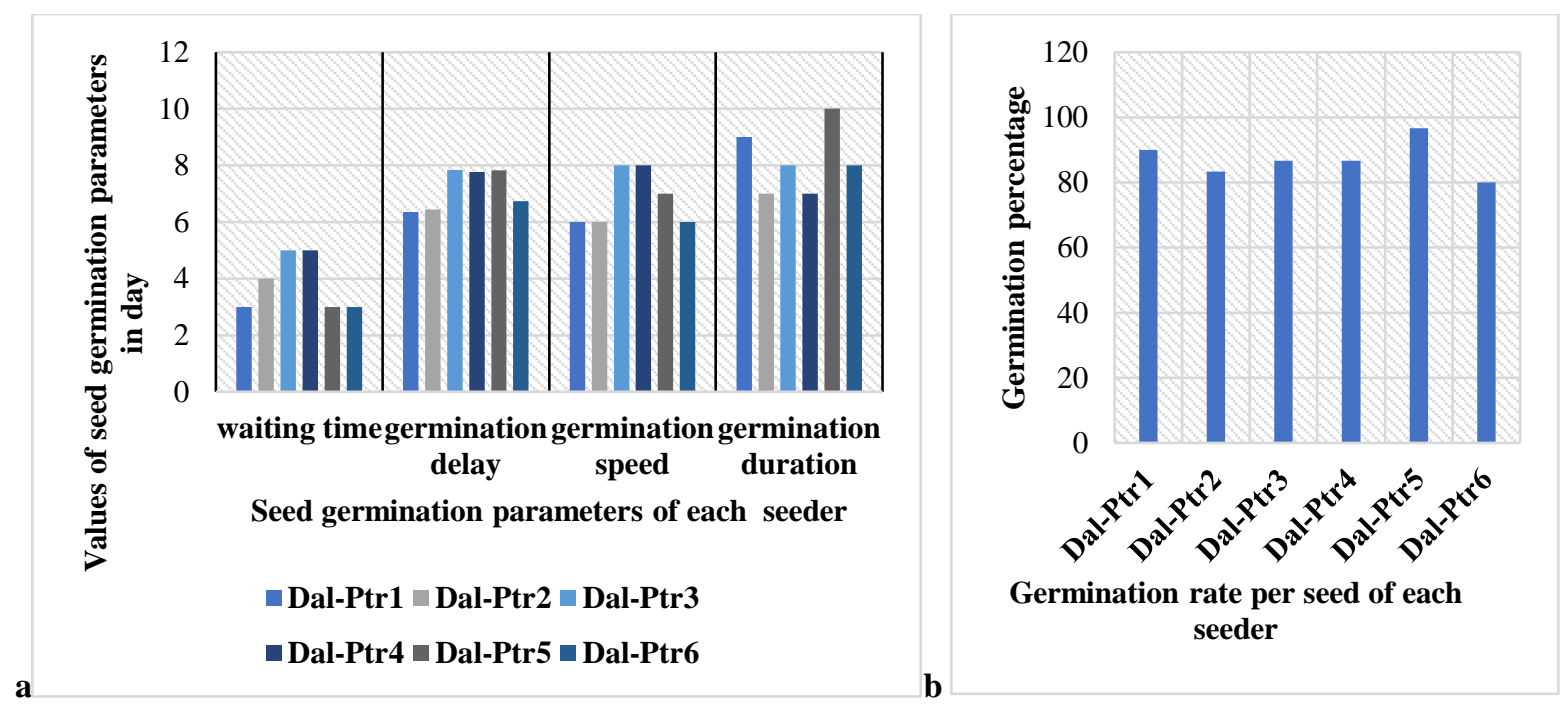

Dal-Ptr1=Seeds from seed tree 1, Dal-Ptr2=Seeds from seed tree 2, Dal-Ptr3=Seeds from seed tree 3, Dal-Ptr4=Seeds from seed tree 4, Dal-Ptr5=Seeds from seed tree 5, Dal-Ptr6=Seeds from seed tree 6

Fig 2. Distribution of seed germination parameters (a: Waiting time, germination delay, germination speed and germination duration; b: germination rate) of the six seed trees in Daloa nursery

Site 3: Montpellier greenhouse

In the CIRAD greenhouse (controlled environment), the shortest germination latency was seven days and was obtained with the seeds from seed trees 2, 5 and 6 (Fig 3a). The shortest germination delay ranged from seven to 14 days, average $9.33 \pm 2.658$ days, with the seeds of seed tree

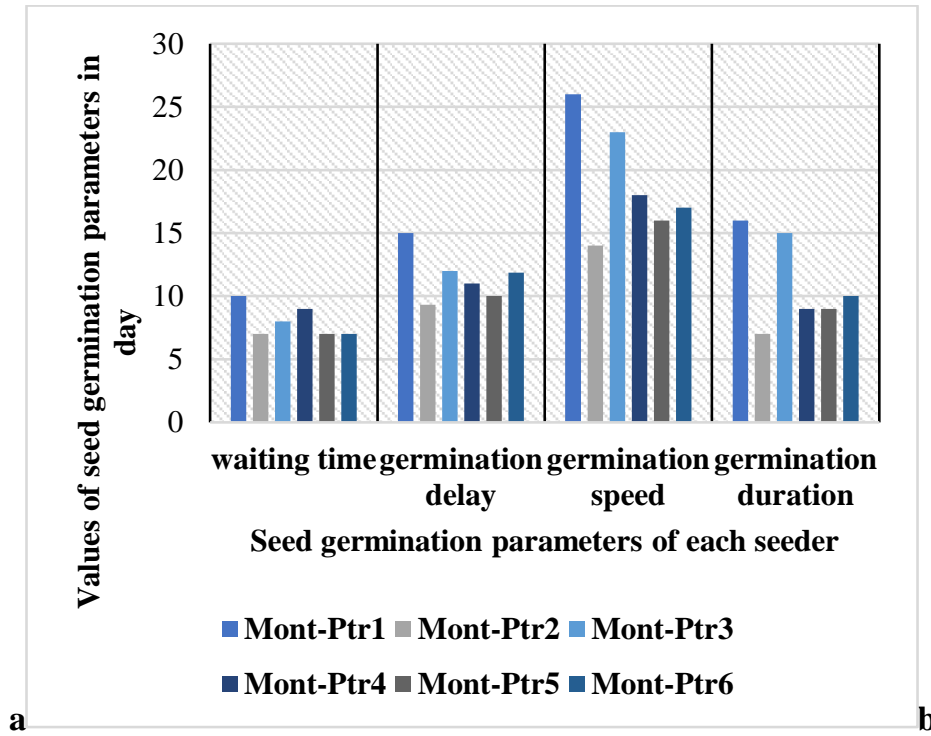

2 (Fig 3a). The seeds of seed tree 2 were also the fastest after 14 days. The shortest germination duration (six days) was observed in the seeds of seed tree 1 with a duration of six days (Fig 3a). The seeds of seed tree 6 had the highest germination rate with a rate of $56.66 \%$ (Fig $3 b$ ).

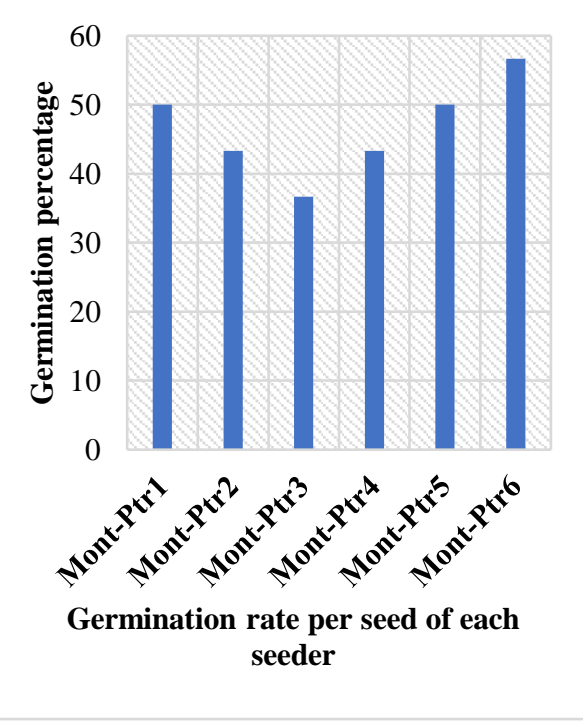

Mont-Ptr1=Seeds from seed tree 1, Mont-Ptr2=Seeds from seed tree 2, Mont-Ptr3=Seeds from seed tree 3, MontMont=Seeds from seed tree 4, Mont-Ptr5=Seeds from seed tree 5, Mont-Ptr6=Seeds from seed tree 6

Fig 3. Distribution of seed germination parameters (a: Waiting time, germination delay, germination speed and germination duration; $b$ : germination rate) of six seed trees in Montpellier greenhouse 


\subsubsection{Development parameters}

Comparison of morphological characteristics of the seedlings from each seed tree in Korhogo site (Table 3) showed that all the seedlings from all the seed trees combined had identical collar diameters $(\mathrm{P}>0.05)$. In contrast, the height, number of leaves, length of leaves, width of leaves and length of internodes all differed significantly $(\mathrm{P}<0.05)$.

At the Daloa site, comparison of morphological characteristics of seedlings from seed trees (Table 3) showed statistically significant variability of variables among the seed trees' seedlings. Height, number of leaves, the length and width of seedling leaves $(\mathrm{P}<0.05)$. The variables collar diameter and internode length were statistically identical from one seedling to another $(\mathrm{P}>$ 0.05).

Comparison of morphological characteristics of the seedlings from each seed tree in Montpellier greenhouse (Table 3) showed that all the morphological characteristics of seedlings grown from each seed tree and observed in the Montpellier site differed from each other $(\mathrm{P}<0.05)$.

Table 3 Comparison of morphological characteristics of seedlings according to the seed trees used per study site

\begin{tabular}{|c|c|c|c|c|c|c|c|}
\hline Sites & Seed trees & SH (cm) & Dcol (mm) & $\mathbf{N}^{\circ} \mathbf{L}$ & LL (cm) & LW (cm) & LIN (cm) \\
\hline \multirow{7}{*}{ 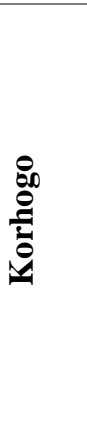 } & Seed tree-1 & $11.34 \pm 1.24 \mathrm{ab}$ & $1.98 \pm 0.21 \mathrm{a}$ & $5.6 \pm 0.44 \mathrm{~b}$ & $5.87 \pm 0.34 \mathrm{a}$ & $5.74 \pm 0.61 \mathrm{a}$ & $1.61 \pm 0.51 \mathrm{~b}$ \\
\hline & Seed tree-2 & $9.7 \pm 1.36 \mathrm{~b}$ & $2.04 \pm 0.51 \mathrm{a}$ & $6.31 \pm 0.41 \mathrm{ab}$ & $6.21 \pm 0.56 \mathrm{a}$ & $6.02 \pm 0.31 \mathrm{a}$ & $2.06 \pm 0.14 \mathrm{a}$ \\
\hline & Seed tree-3 & $12.6 \pm 0.74 \mathrm{ab}$ & $2.06 \pm 0.34 \mathrm{a}$ & $7.54 \pm 0.53 \mathrm{a}$ & $5.37 \pm 0.47 \mathrm{ab}$ & $5.2 \pm 0.22 \mathrm{ab}$ & $2.41 \pm 0.16 \mathrm{a}$ \\
\hline & Seed tree- 4 & $15.74 \pm 1.51 \mathrm{a}$ & $2.62 \pm 0.42 \mathrm{a}$ & $6.31 \pm 0.53 \mathrm{ab}$ & $5.64 \pm 0.47 \mathrm{ab}$ & $5.08 \pm 0.34 \mathrm{ab}$ & $1.86 \pm 0.23 \mathrm{~b}$ \\
\hline & Seed tree-5 & $12.63 \pm 1.47 \mathrm{ab}$ & $2.31 \pm 0.13 \mathrm{a}$ & $7.51 \pm 0.62 \mathrm{a}$ & $4.62 \pm 0.53 b$ & $4.12 \pm 0.25 b$ & $2.19 \pm 0.24 \mathrm{a}$ \\
\hline & Seed tree- 6 & $10.63 \pm 1.71 \mathrm{~b}$ & $2.58 \pm 0.26 \mathrm{a}$ & $5.1 \pm 0.33 \mathrm{~b}$ & $4.23 \pm 0.72 b$ & $3.8 \pm 0.62 \mathrm{~b}$ & $1.57 \pm 0.06 \mathrm{~b}$ \\
\hline & $\operatorname{Pr}>\mathbf{F}$ & 0.0001 & 0.652 & 0.001 & 0.0071 & 0.0311 & 0.0114 \\
\hline \multirow{7}{*}{$\frac{\text { อ }}{\overparen{\pi}}$} & Seed tree-1 & $16.38 \pm 1.21 \mathrm{ab}$ & $2.05 \pm 0.25 \mathrm{a}$ & $5.4 \pm 0.71 \mathrm{~b}$ & $4.7 \pm 0.17 \mathrm{ab}$ & $3.98 \pm 0.22 b$ & $2.8 \pm 0.10 \mathrm{a}$ \\
\hline & Seed tree-2 & $14.12 \pm 1.11 \mathrm{ab}$ & $2.64 \pm 0.23 \mathrm{a}$ & $7.6 \pm 0.62 \mathrm{ab}$ & $5.8 \pm 0.27 \mathrm{a}$ & $5.1 \pm 0.41 \mathrm{a}$ & $3.8 \pm 0.13 \mathrm{a}$ \\
\hline & Seed tree-3 & $13.5 \pm 1.53 \mathrm{~b}$ & $2.67 \pm 0.32 \mathrm{a}$ & $7.58 \pm 0.42 \mathrm{ab}$ & $5.56 \pm 0.31 \mathrm{a}$ & $4.54 \pm 0.42 \mathrm{ab}$ & $3.2 \pm 0.21 \mathrm{a}$ \\
\hline & Seed tree-4 & $14.57 \pm 1.41 \mathrm{ab}$ & $2.33 \pm 0.22 \mathrm{a}$ & $5.65 \pm 0.34 b$ & $4.78 \pm 0.32 \mathrm{ab}$ & $3.68 \pm 0.34 \mathrm{~b}$ & $2.4 \pm 0.11 \mathrm{a}$ \\
\hline & Seed tree-5 & $18.29 \pm 0.84 \mathrm{a}$ & $2.71 \pm 0.14 \mathrm{a}$ & $8.54 \pm 0.36 \mathrm{a}$ & $5.62 \pm 0.12 \mathrm{a}$ & $5.55 \pm 0.61 \mathrm{a}$ & $3.7 \pm 0.51 \mathrm{a}$ \\
\hline & Seed tree- 6 & $16.62 \pm 1.35 \mathrm{ab}$ & $2.63 \pm 0.34 \mathrm{a}$ & $7.21 \pm 0.44 \mathrm{ab}$ & $3.8 \pm 0.51 \mathrm{~b}$ & $3.9 \pm 0.31 \mathrm{~b}$ & $3 \pm 0.21 \mathrm{a}$ \\
\hline & $\operatorname{Pr}>\mathbf{F}$ & 0.041 & 0.812 & 0.011 & 0.0221 & 0.001 & 0.921 \\
\hline \multirow{7}{*}{ 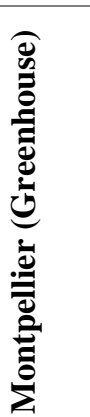 } & Seed tree-1 & $14.65 \pm 1.22 \mathrm{~b}$ & $2.95 \pm 0.36 \mathrm{a}$ & $6.7 \pm 0.39 \mathrm{ab}$ & $5.24 \pm 0.52 \mathrm{a}$ & $5.8 \pm 0.34 \mathrm{a}$ & $3.1 \pm 0.41 \mathrm{ab}$ \\
\hline & Seed tree-2 & $16.07 \pm 1.34 \mathrm{ab}$ & $1.55 \pm 0.43 \mathrm{~b}$ & $7.6 \pm 0.53 \mathrm{ab}$ & $4.79 \pm 0.34 \mathrm{ab}$ & $4.3 \pm 0.41 \mathrm{ab}$ & $3.61 \pm 0.16 \mathrm{ab}$ \\
\hline & Seed tree-3 & $18.7 \pm 1.52 \mathrm{a}$ & $2.61 \pm 0.34 \mathrm{a}$ & $7.4 \pm 0.47 \mathrm{ab}$ & $5.8 \pm 0.22 \mathrm{a}$ & $5.7 \pm 0.16 \mathrm{a}$ & $4.31 \pm 0.31 \mathrm{ab}$ \\
\hline & Seed tree-4 & $16.77 \pm 1.37 \mathrm{ab}$ & $2.31 \pm 0.12 \mathrm{a}$ & $5.97 \pm 0.63 b$ & $4.31 \pm 0.34 \mathrm{ab}$ & $3.5 \pm 0.24 \mathrm{~b}$ & $2.34 \pm 0.25 b$ \\
\hline & Seed tree-5 & $16.42 \pm 1.43 \mathrm{ab}$ & $2.92 \pm 0.15 \mathrm{a}$ & $8.3 \pm 0.46 \mathrm{a}$ & $4.53 \pm 0.51 \mathrm{ab}$ & $4.36 \pm 0.21 \mathrm{ab}$ & $3.42 \pm 0.17 \mathrm{ab}$ \\
\hline & Seed tree- 6 & $15.2 \pm 1.65 \mathrm{ab}$ & $2.87 \pm 0.12 \mathrm{a}$ & $6.96 \pm 0.26 \mathrm{ab}$ & $3.97 \pm 0.13 b$ & $3.82 \pm 0.34 \mathrm{~b}$ & $5.08 \pm 0.37 \mathrm{a}$ \\
\hline & $\operatorname{Pr}>F$ & 0.001 & 0.04991 & 0.0001 & 0.001 & 0.001 & 0.0001 \\
\hline
\end{tabular}

For each character, values with the same letters are not statistically different at the $5 \%$ threshold.

SH: seedling height; Dcol: Diameter at the collar of the seedlings; $\mathbf{N}^{\circ} \mathbf{L}$ : Number of leaves; $\mathbf{L L}$ : Leaf length; $\mathbf{L W}$ : Leaf Width; LIN: Length of the internodes; cm: centimetres; mm: millimetres.

3.2. Global influence of study sites and seed trees on seed germination and seedling development in Pterocarpus erinaceus

3.2.1. Influence on seeds germination
Figure 4 is an overview of all germination parameters observed at the three study sites. She indicates that the highest germination rate was measured at the Daloa site. However, the highest values for the four other parameters 
(waiting time, germination delay, germination speed and germination spread time) were recorded in Montpellier greenhouse.
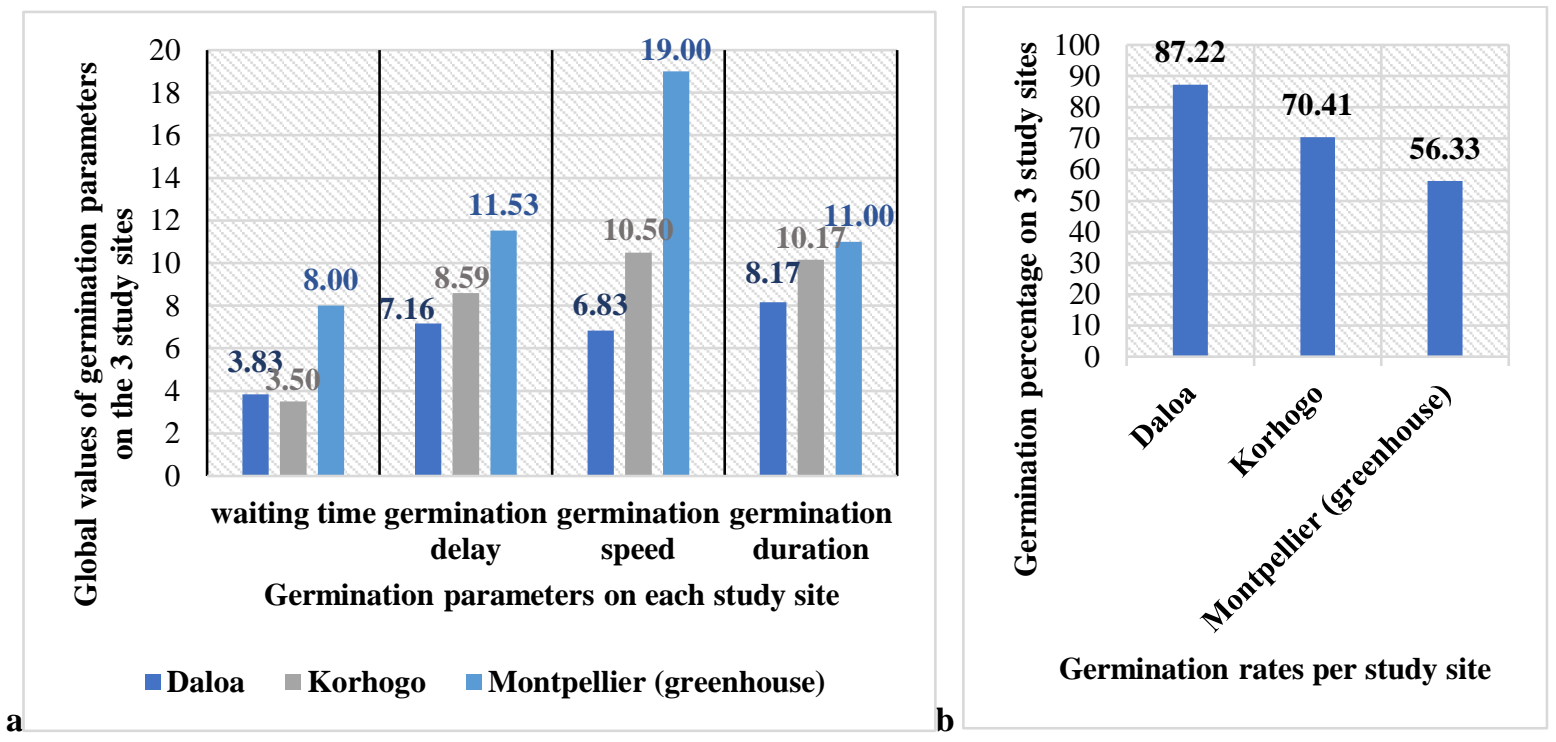

Fig 4. Global distribution of each germination parameter (a: Waiting time, germination delay, germination speed and germination duration; $b$ : germination rate) for the all study sites.

According to Table 4, all germination parameters differed statistically $(\mathrm{P}<0.05)$ from site to site, except for germination spread, which is identical from site to site $(\mathrm{P}>0.05)$. The analysis of variance (Table 4$)$ of germination parameters according to the types of seed trees used showed that all observed variables were statistically identical from one seed tree to another $(\mathrm{P}>0.05)$ for all three sites.

Table 4 Comparison of germination parameters according to the bioclimates and seed trees used

\begin{tabular}{cccccc}
\hline $\begin{array}{c}\text { Sites or } \\
\text { bioclimates/Seed } \\
\text { trees }\end{array}$ & waiting time & $\begin{array}{c}\text { germination } \\
\text { delay }\end{array}$ & $\begin{array}{c}\text { germination } \\
\text { speed }\end{array}$ & $\begin{array}{c}\text { germination } \\
\text { duration }\end{array}$ & $\begin{array}{c}\text { germination } \\
\text { rate }\end{array}$ \\
\hline Korhogo & $3.50 \pm 0.22 \mathbf{b}$ & $8.59 \pm 0.58 \mathbf{b}$ & $10.50 \pm 0.76 \mathbf{b}$ & $10.17 \pm 0.48 \mathbf{a}$ & $70.41 \pm 3.70 \mathbf{b}$ \\
\hline Daloa & $3.83 \pm 0.40 \mathbf{b}$ & $7.16 \pm 0.29 \mathbf{b}$ & $6.83 \pm 0.40 \mathbf{c}$ & $8.17 \pm 0.47 \mathbf{a}$ & $87.22 \pm 2.34 \mathbf{a}$ \\
\hline $\begin{array}{c}\text { Montpellier } \\
\text { Greenhouse })\end{array}$ & $8 \pm 0.52 \mathbf{a}$ & $11.53 \pm 0.81 \mathbf{a}$ & $19 \pm 1.86 \mathbf{a}$ & $11 \pm 1.48 \mathbf{a}$ & $56.33 \pm 3.36 \mathbf{c}$ \\
\hline Pr $>$ F & $\mathbf{0 . 0 0 0 1}$ & $\mathbf{0 . 0 0 0 4}$ & $\mathbf{0 . 0 0 1}$ & $\mathbf{0 . 1 2 5 1}$ & $\mathbf{0 . 0 0 0 1}$ \\
\hline Seed tree-1 & $5.67 \pm 2.18 \mathbf{a}$ & $9.18 \pm 2.91 \mathbf{a}$ & $13.67 \pm 6.23 \mathbf{a}$ & $11.33 \pm 2.33 \mathbf{a}$ & $65.55 \pm 12.37 \mathbf{a}$ \\
\hline Seed tree-2 & $5 \pm 1 \mathbf{a}$ & $8.19 \pm 0.89 \mathbf{a}$ & $10 \pm 2.31 \mathbf{a}$ & $7.67 \pm 0.66 \mathbf{a}$ & $66.66 \pm 9.62 \mathbf{a}$ \\
\hline Seed tree-3 & $5.33 \pm 1.45 \mathbf{a}$ & $9.63 \pm 1.23 \mathbf{a}$ & $13.33 \pm 4.84 \mathbf{a}$ & $11 \pm 2.08 \mathbf{a}$ & $67.77 \pm 10.59 \mathbf{a}$ \\
\hline Seed tree-4 & $6 \pm 1.53 \mathbf{a}$ & $9.47 \pm 0.94 \mathbf{a}$ & $12.33 \pm 2.96 \mathbf{a}$ & $8.67 \pm 0.88 \mathbf{a}$ & $71.99 \pm 8.87 \mathbf{a}$ \\
\hline Seed tree-5 & $4.33 \pm 1.33 \mathbf{a}$ & $8.52 \pm 0.74 \mathbf{a}$ & $11 \pm 2.65 \mathbf{a}$ & $10 \pm 0.58 \mathbf{a}$ & $78.44 \pm 10.05 \mathbf{a}$ \\
\hline Seed tree-6 & $4.33 \pm 1.33 \mathbf{a}$ & $9.57 \pm 1.50 \mathbf{a}$ & $12.33 \pm 3.28 \mathbf{a}$ & $10 \pm 1.15 \mathbf{a}$ & $77.50 \pm 3.82 \mathbf{a}$ \\
\hline Pr $>\mathbf{F}$ & $\mathbf{0 . 9 5 3 4}$ & $\mathbf{0 . 9 7 6 2}$ & $\mathbf{0 . 9 8 4 3}$ & $\mathbf{0 . 5 0 1 1}$ & $\mathbf{0 . 8 7 8 4}$
\end{tabular}

For each character, values with the same letters are not statistically different at the $5 \%$ threshold.

Table 5 shows a strong positive correlation between first germination and germination delay and then germination speed at all three study sites: between germination delay and germination speed and then 
germination duration and between germination speed and germination time. However, this matrix indicated a negative correlation between germination rate and waiting time, germination delay and germination speed.

Table 5 Total correlation matrix (Pearson) between germination parameters

\begin{tabular}{cccccc}
\hline Variables & Waiting time & $\begin{array}{c}\text { Germination } \\
\text { delay }\end{array}$ & $\begin{array}{c}\text { Germination } \\
\text { speed }\end{array}$ & $\begin{array}{c}\text { Germination } \\
\text { duration }\end{array}$ & $\begin{array}{c}\text { Germination } \\
\text { rate }\end{array}$ \\
\hline Waiting time & $\mathbf{1}$ & & & \\
\hline Germination delay & $\mathbf{0 . 7 9 6}$ & $\mathbf{1}$ & $\mathbf{1}$ & \\
\hline Germination speed & $\mathbf{0 . 8 7 0}$ & $\mathbf{0 . 9 4 3}$ & $\mathbf{1}$ & \\
\hline Germination duration & 0.396 & $\mathbf{0 . 7 3 3}$ & $\mathbf{0 . 7 4 6}$ & -0.393 & $\mathbf{1}$
\end{tabular}

Values in bold are different from 0 at significance level alpha $=0.05$

\subsubsection{Influence on seedling development}

The results (Table 6) showed that only the heights and lengths of the internodes differed from one bioclimate to another $(\mathrm{P}<0.05)$. The collar diameter, number of leaves, the length and width of the leaves were the same from one bioclimate to another $(\mathrm{P}>0.05)$.
Analysis of variance of the seedlings from one seed tree to another at all three sites (Table 6) indicated that only the number of seedling leaves and leaf length differed significantly in seedlings from one seed tree to another $(\mathrm{P}<$ 0.05). Height, diameter, leaf width and successive internode lengths of seedlings were all statistically identical from one seedling to another $(\mathrm{P}>0.05)$.

Table 6 Comparison of morphological parameters according to the bioclimates and seed trees used

\begin{tabular}{|c|c|c|c|c|c|c|}
\hline $\begin{array}{c}\text { Sites or } \\
\text { bioclimates/Seed } \\
\text { trees }\end{array}$ & SH (cm) & Dcol (mm) & $\mathbf{N}^{\circ} \mathbf{L}$ & LL (cm) & LW (cm) & LIN (cm) \\
\hline Daloa & $15.58 \pm 0.74 \mathbf{a}$ & $\begin{array}{c}2.50 \pm 0.11 \\
\mathbf{a}\end{array}$ & $\begin{array}{c}6.99 \pm 0.49 \\
\mathbf{a}\end{array}$ & $\begin{array}{c}5.04 \pm 0.31 \\
\mathbf{a}\end{array}$ & $\begin{array}{c}4.46 \pm 0.30 \\
\mathbf{a}\end{array}$ & $\begin{array}{c}3.15 \pm 0.22 \\
\mathbf{a}\end{array}$ \\
\hline Korhogo & $12.11 \pm 0.86 \mathbf{b}$ & $\begin{array}{c}2.26 \pm 0.12 \\
\mathbf{a}\end{array}$ & $\begin{array}{c}6.39 \pm 0.40 \\
\mathbf{a}\end{array}$ & $\begin{array}{c}5.32 \pm 0.31 \\
\mathbf{a}\end{array}$ & $\begin{array}{c}4.99 \pm 0.36 \\
\mathbf{a}\end{array}$ & $\begin{array}{c}1.95 \pm 0.14 \\
\text { b }\end{array}$ \\
\hline $\begin{array}{c}\text { Montpellier } \\
\text { (Greenhouse) }\end{array}$ & $16.30 \pm 0.58 \mathbf{a}$ & $\begin{array}{c}2.53 \pm 0.22 \\
\mathbf{a}\end{array}$ & $\begin{array}{c}7.15 \pm 0.33 \\
\mathbf{a}\end{array}$ & $\begin{array}{c}4.77 \pm 0.27 \\
\mathbf{a}\end{array}$ & $\begin{array}{c}4.58 \pm 0.39 \\
\mathbf{a}\end{array}$ & $\begin{array}{c}3.64 \pm 0.39 \\
\mathbf{a}\end{array}$ \\
\hline $\operatorname{Pr}>\mathbf{F}$ & 0.0024 & 0.4292 & 0.4168 & 0.4455 & 0.5456 & 0.0014 \\
\hline Seed tree-1 & $14.12 \pm 1.48 \mathbf{a}$ & $\begin{array}{c}2.33 \pm 0.31 \\
\mathbf{a}\end{array}$ & $\begin{array}{c}5.90 \pm 0.40 \\
\text { b }\end{array}$ & $\begin{array}{c}5.27 \pm 0.34 \\
\text { ab }\end{array}$ & $\begin{array}{c}5.17 \pm 0.59 \\
\mathbf{a}\end{array}$ & $\begin{array}{c}2.50 \pm 0.45 \\
\mathbf{a}\end{array}$ \\
\hline Seed tree-2 & $13.29 \pm 1.88 \mathbf{a}$ & $\begin{array}{c}2.08 \pm 0.31 \\
\mathbf{a}\end{array}$ & $\begin{array}{c}7.17 \pm 0.43 \\
\text { ab }\end{array}$ & $\begin{array}{c}5.60 \pm 0.42 \\
\mathbf{a}\end{array}$ & $\begin{array}{c}5.14 \pm 0.49 \\
\mathbf{a}\end{array}$ & $\begin{array}{c}3.16 \pm 0.55 \\
\mathbf{a}\end{array}$ \\
\hline Seed tree-3 & $14.93 \pm 1.90 \mathbf{a}$ & $\begin{array}{c}2.45 \pm 0.19 \\
\mathbf{a}\end{array}$ & $\begin{array}{c}7.51 \pm 0.05 \\
\text { ab }\end{array}$ & $\begin{array}{c}5.58 \pm 0.12 \\
\mathbf{a}\end{array}$ & $\begin{array}{c}5.15 \pm 0.34 \\
\mathbf{a}\end{array}$ & $\begin{array}{c}3.31 \pm 0.55 \\
\mathbf{a}\end{array}$ \\
\hline Seed tree-4 & $15.69 \pm 0.64 \mathbf{a}$ & $\begin{array}{c}2.42 \pm 0.10 \\
\mathbf{a}\end{array}$ & $\begin{array}{c}5.98 \pm 0.19 \\
\text { b }\end{array}$ & $\begin{array}{c}4.91 \pm 0.39 \\
\mathbf{a b}\end{array}$ & $\begin{array}{c}4.09 \pm 0.49 \\
\mathbf{a}\end{array}$ & $\begin{array}{c}2.20 \pm 0.17 \\
\mathbf{a}\end{array}$ \\
\hline Seed tree-5 & $15.78 \pm 1.66 \mathbf{a}$ & $\begin{array}{c}2.65 \pm 0.18 \\
\mathbf{a}\end{array}$ & $\begin{array}{c}8.12 \pm 0.31 \\
\mathbf{a}\end{array}$ & $\begin{array}{c}4.92 \pm 0.35 \\
\text { ab }\end{array}$ & $\begin{array}{c}4.68 \pm 0.44 \\
\mathbf{a}\end{array}$ & $\begin{array}{c}3.10 \pm 0.46 \\
\mathbf{a}\end{array}$ \\
\hline Seed tree-6 & $14.15 \pm 1.81 \mathbf{a}$ & $\begin{array}{c}2.69 \pm 0.09 \\
\mathbf{a}\end{array}$ & $\begin{array}{c}6.42 \pm 0.66 \\
\text { b }\end{array}$ & $4 \pm 0.13 \mathbf{b}$ & $\begin{array}{c}3.84 \pm 0.03 \\
\mathbf{a}\end{array}$ & $\begin{array}{c}3.22 \pm 1.02 \\
\mathbf{a}\end{array}$ \\
\hline $\operatorname{Pr}>F$ & 0.8629 & 0.4272 & 0.0094 & $\mathbf{0 . 0 3 3 5}$ & 0.1900 & 0.7129 \\
\hline
\end{tabular}


For each character, values with the same letters are not statistically different at the $5 \%$ threshold.

SH: seedling height; Dcol: Diameter at the collar of the seedlings; $\mathbf{N}^{\circ} \mathbf{L}$ : Number of leaves; LL: Leaf length; LW: Leaf Width; LIN: Length of the internodes; cm: centimetres; mm: millimetres.

Figure 5 shows the projection of bioclimates and morphological parameters for all seedlings on PCA 1-2 (biplot). Analysis of the matrix of factor weights showed that two components explained $100 \%$ of the variability and are therefore highly relevant in explaining the total variation between the morphological characteristics of the seedlings and the bioclimates. Plan 1-2 s characterized by eigenvalues of $95.40 \%$ for axis F1 and $4.60 \%$ for axis F2. The different descriptors contributing to the formation of the first component $(\mathrm{F} 1)$ and the second component $(\mathrm{F} 2)$ revealed two groups. The first group consisted of the Montpellier (greenhouse) and the Daloa site characterized by higher heights, collar diameters, numbers of leaves and internode lengths of the seedlings than at the Korhogo site. The second group consisted of the Korhogo site, which was characterized by seedlings with longer and wider leaves than those at the Daloa site and the Montpellier greenhouse.

\section{Biplot (axis F1 and F2 : 100.00\%)}

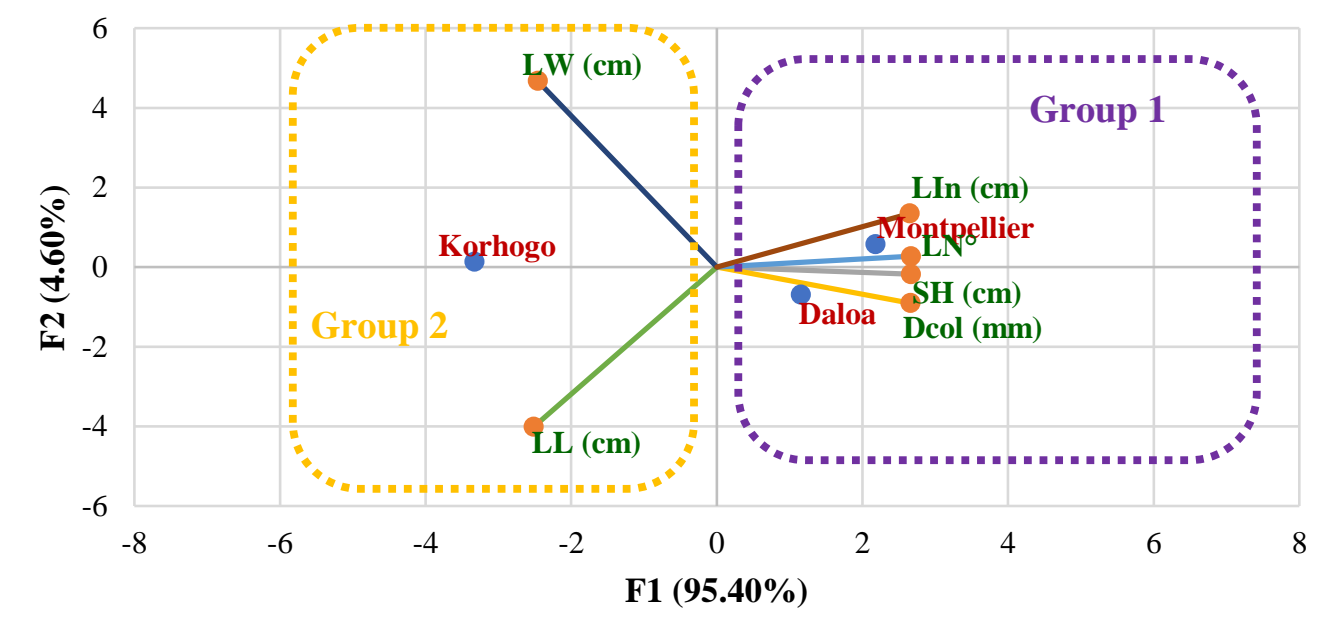

SH: seedling height; Dcol: Diameter at the collar of the seedlings; $\mathbf{N}^{\circ} \mathbf{L}$ : Number of leaves; LL: Leaf length; LW: Leaf Width; LIN: Length of internodes; cm: centimetres; mm: millimetres.

Fig 5. Projection of bioclimates and morphological parameters observed in PCA Plan 1-2 as a function of axis type

\section{DISCUSSION}

\subsection{Germination parameters}

The germination of Pterocarpus erinaceus is epigeal generally. Our results confirm those of Adou et al., in 2013 and N'golo et al., in 2018, who all found the same type of germination. At germination, the leaves are simple with alternating spiral phyllotaxis and it is over time that compound leaves appear. This is due to the fact that in the very young stage, the seedling depends on the reserve (starch) contained in the embryo (seed) which only serves to emit simple pre-leaves with long petioles. These preleaves take over via photosynthetic activity following the disappearance of the embryo and the cotyledonary leaves. The seedling thus becomes independent and expresses its normal organogenesis by producing compound leaves (after 84 days and at 100 days on average). In fact, the cost of building its authentic development is high and therefore requires progressive adaptation. The seeds were shelled in our study because of pericardial dormancy. Indeed, studies by Lauries in 1974, Rajendrudu and Naidu in 2001, Adou et al in 2013, Ameri et al in 2017 and N'golo et al in 2018 respectively on Pterocarpus angolensis, Pterocarpus santalinus, Pterocarpus erinaceus, Faidherbia albida and Pterocarpus erinaceus showed that the pericarp has a negative effect on germination rate and germination speed.

Our results showed overall that the seeds germination performances in Montpellier were poor; this is due to poor seed storage (long storage at an average temperature of 28 $\left.{ }^{\circ} \mathrm{C}\right)$. In fact, the seeds were harvested in April, the peeled seeds were stored at room temperature $\left(25^{\circ} \mathrm{C}\right.$ night and 32 ${ }^{\circ} \mathrm{C}$ day) for one and a half months until their shipment in Montpellier in mid-June. As the seeds were not stored at a low temperature, we think that the heat had a negative effect on the germination capacity of the seeds like in the study of 
Pterocarpus erinaceus seeds by N'golo et al., in 2018 in the Haut Bandama reserve in Côte d'Ivoire and in the study of Faiherbia albida seeds by Ameri et al. (2017). However, good performances were recorded in Daloa probably due to the humid tropical climate that favoured the harmonious development of forest species and the relatively rich soil. Indeed, several studies have demonstrated the effect of climate and soil poverty on the germination of certain species (Giordano 1972; Soloviev et al. 2004; Dianda et al. 2009; Sambe et al. 2010). In addition, the seeds were sown immediately after harvesting and shelling at the Korhogo and Daloa sites, which explains the short germination latency times observed at these two sites; moreover, Daloa is a transition zone between forest and savannah, both savannah and forest species are found there, and all crops that depend on the savannah and forest zones develop there without exception. Korhogo follows just after Daloa in terms of recorded performances, indeed Korhogo is part of the distribution area of Pterocarpus erinaceus (Adjonou et al. 2010; Ouedraogo et al., 2006; Kossi et al., 2015; Anonymous 2016). In the same distribution area (in Niger), Amani et al. (2015) reported high germination rates ranging from 70 to $100 \%$ in four species of Combretaceae with germination duration of 9 to 18 days. In spite of the absence of pre-treatment of the seeds, the results were satisfactory, in contrast to those of Adou et al. (2013), who reported a germination rate of $29 \%$, a latency time of four days and a germination duration of 11 days. In the study by N'golo et al. (2018), the seeds were pre-treated, and the maximum germination rate was $68.5 \%$ with a maximum delay of days and a maximum germination speed of 11.42 days. Ameri et al. (2017) obtained a low germination rate (27\%) with nonpre-treated seeds of Faidherbia albida; whereas Ahoton et al., in 2009 and Amonum et al., in 2016 obtained a high germination rate with treated seeds of Parkia biglobosa.

Analysis of variance indicated that there was no significant difference between germination parameters according to the seed trees, however germination was expressed differently from one site to another except for the germination spread parameter which was statistically identical regardless of the study site. This is because although the composition and variability of seeds were practically the same (size and mass) from one seed tree to another, the environmental conditions (climate and soil type) were influenced germination. this is the case for many study (Assogbadjo et al., 2005, 2006; Dianda et al., 2009; Sambe et al., 2010). Indeed, the plant adapts to the conditions imposed by the microclimate (environment of location).

The correlation matrix showed that the germination rate is negatively correlated with all other germination parameters. This means that the higher the germination rate, the lower the germination latency time, the shorter the germination delay, the faster the speed (fewer days) and the shorter the germination spread.

\subsection{Development parameters}

Generally high values were recorded at the Montpellier greenhouse because of the stable climate (no temperature fluctuations or insect attacks) in the greenhouse and a substrate rich in mineral elements that allowed the seedlings to develop well and flourish. Morphological parameters were moderately poor in Korhogo due to the unstable dry tropical climate and abundant attacks by larvae. Studies by Salazar and Quesada (1987), Dianda and Chalifour (2002), Maranz and Wiesman (2003), Soloviev et al. (2004) have already shown the effect of the original climate or climatic zone, soil, mother trees and soil poverty on the germination, growth and morphological development of several plant species. The results obtained by N'golo et al. (2018) contradict ours, as they indicate that at two weeks, the number of leaves was six, the average height of the seedlings was $7.5 \mathrm{~cm}$ and the diameter was $1 \mathrm{~mm}$, and three months later the seedlings reached a diameter of $5 \mathrm{~mm}$ with an average height of $40 \mathrm{~cm}$. In the first results of SODEFOR research on Pterocarpus erinaceus, Adou et al. (2013) reported average plantlet heights of $4.5 \mathrm{~cm}$ and $5.4 \mathrm{~cm}$ in, respectively, three weeks and one month. Using five growth accelerators on a legume (Parkia biglobosa) of the same family (Fabaceae) as Pterocapus erinaceus in Benin at 140 days, Gnanglé et al. (2010) reported an average seedling height of $26.3 \mathrm{~cm}$, an average diameter of $6.6 \mathrm{~mm}$ with an average of 8.5 leaves. On the other hand, in Niger, Amani et al. (2015), reported heights ranging from $7.71 \mathrm{~cm}$ to 25.8 $\mathrm{cm}$ with diameters ranging from $2.68 \mathrm{~mm}$ to $3.22 \mathrm{~mm}$ in four families of Combretaceae.

Analysis of variance showed that there was no significant difference from one seed tree to another for morphological parameters, and only the number of leaves and leaf length differed from one seed tree to another. However, the site only influenced the height of seedlings and the length of internodes. The climatic conditions of the site affected seedling length. The more favourable the conditions (rich soil and humid tropical climate), the vigor and larger the seedling (Montpellier and Daloa sites). This fact was confirmed by the principal component analysis, which indicated that in Montpellier and Daloa sites, seedling heights, collar diameters, leaf counts and internode lengths were higher than those observed in Korhogo.

\section{CONCLUSION}

This study found that a long shelf life of Pterocarpus erinaceus seed at room temperature had a negative effect on the performance and germination of dehulled seeds. The study also showed that the germinative expression was 
basically the same from one seed tree to another and that only the site significantly influenced the germination expression through the climate and the type of soil. Correlations showed that the higher the germination rate, the shorter the waiting time, the shorter the germination delay, the slower the germination speed and the shorter the germination duration. The study also showed that a stable (greenhouse), healthy climate (with no larval attacks), rich soil and a humid tropical climate are essential for the harmonious development of Pterocarpus erinaceus seedlings, as the height, diameter, number of leaves and length of internodes are higher. The seedlings morphological parameters were almost identical from one seed tree to another ( $p>0.05)$, while the site significantly influenced the height and length of the seedling internodes $(\mathrm{p}<0.05)$. Principal component analysis showed that the Montpellier greenhouse and the Daloa site are favorable because they resulted in greater heights, collar diameters, leaf counts and internode lengths than the Korhogo site. these results can be a decision-making guide for the artificial regeneration of Pterocarpus erinaceus stands, for the establishment of permanent plots within the framework of reforestation or agroforestry programmes based on this species from a nursery. They are a useful source of information for nurserymen and for the sustainable management of Pterocarpus erinaceus forest populations in Côte d'Ivoire and the West African sub-region.

\section{ACKNOWLEDGEMENTS}

This study was financed by the Ministry of Higher Education and Scientific Research of Côte d'Ivoire, the French Development Agency and IRD (Institut de Recherche pour le Developpement) within the framework of PRESeD-CI 2 (Renewed Partnership for Research for Development in Côte d'Ivoire) and C2D (Debt Reduction Contract) of the AMRUGE-CI project (Support for the Modernization and Reform of Universities and Grandes Ecoles of Côte d'Ivoire). The authors are grateful to the Centre de Coopération International de Recherche Agronomique pour le Développement (CIRAD) for providing a greenhouse (controlled environment) and the technical equipment necessary to conduct the study.

\section{CREDIT AUTHORSHIP CONTRIBUTION STATEMENT}

Beda I Adji: Conception, methodology, supervision, software, formal analysis, writing the paper, resources, data acquisition and analysis. Sélastique D Akaffou: Paper reading, Project administration, methodology, resources, data acquisition, supervision, writing the paper - original project, research and acquisition of funding. Henri K
Kouassi, Yao P Houphouet and Jerôme Duminil: writing the paper - original project, research and acquisition of funding. Sylvie A Sabatier: Paper reading, Project administration, methodology, resources, data acquisition, supervision, writing the paper - original project, research and acquisition of funding.

\section{CONFLICT OF INTEREST}

The authors declare that there is no conflict of interest either between the authors, or between the organisations which financed the work, or on the site used for the experiments. All the authors agree to the publication of the submitted version of the paper.

\section{DATA AVAILABILITY}

The datasets generated during and/or analysed during the current study are available from the corresponding author on reasonable request.

\section{REFERENCES}

[1] Adji, B.I., Akaffou, S.D., Kouassi, K.H., Houphouet, Y.P., Duminil, J. and Sabatier, S. (2020) Influence of Different Environments on Germination Parameters and Seedling Morphology in Khaya senegalensis (Desr.) A. Juss (Meliaceae). American Journal of Plant Sciences, 11, 15791600. https://doi.org/10.4236/ajps.2020.1110114

[2] Adjonou K, Ali N, Kokutse AD, Kokou K (2010) Étude de la dynamique des peuplements naturels de Pterocarpus erinaceus Poir. (Fabaceae) surexploités au Togo. Bois et Forêts des Tropiques, $\mathrm{N}^{\circ} 306$ (1), pp 33-43.

[3] Adou k, konan kJc, Diarra F (2013) Note sur le Vène. Premiers résultats de travaux de recherche sur le vène, a la sodefor. 2p. $\quad$ http://ci.chmcbd.net/biodiversity/fauneflore/flore/flore-terrestre/notesur-le-vene

[4] Ahoton LE, Adjakpa JB, M'po IM, Akpo EL (2009) Effet des prétraitements des semences sur la germination de Prosopis africana (Guill., Perrot. et Rich.) Taub., (Césalpiniacées). Tropicultura 27 (4) : 233-238.

[5] AISA (2019) Association Ivoirienne des Sciences Agronomiques. 10 p. https://pratik.ci/annuaire

[6] Akaffou SD, Kouamé KA, Gore BBN, Abessika YG, Kouassi KH, Hamon P, Sabatier S, Duminil J (2019) Effect of the seeds provenance and treatment on the germination rate and plants growth of four forest trees species of Côte d'Ivoire. J. For. Res. 10 p. DOI : https ://doi.org/10.1007/s11676-019-01064-y

[7] Anonymous (2019) Pterocarpus erinaceus Poir. First published in Lamarck's JBAM, Encycl. 5: 728 (1804). In the GBIF Secretariat (2019). Taxonomy of the GBIF Ridge. Checklist dataset https://doi.org/10.15468/39omei accessed via GBIF.org on 2021-03-05. 
[8] Anonymous (2019) Https:// www.fr-climatedata.org. Accessed in October 2019.

[9] Anonymous (2016) https://uses.plantnetproject.org/en/Pterocarpus_erinaceus_(PROTA). https:// www.prota4u.org/database /protav8.asp? $\mathrm{fr}=1 \& \mathrm{~h}=\mathrm{M}$ $4 \& \mathrm{t}=$ Pterocarpus, erinaceus $\& \mathrm{p} \quad=$ Pterocarpus+erinaceus\# Synonyms

[10] Amani MM, Inoussa I, Dan Guimbo A, Mahamane M, Saadou AM, Lykke (2015) Germination et croissance de quatre espèces de Combretaceae en pépinière. Tropicultura 33 (2) : 123-145

[11] Ameri AH, Daldoum AMD (2017) Effect of different pretreatment methods and materials on germination potential of Faidherbia albida seeds, Scholars Journal of Agriculture and Veterinary Sciences 4 (3) : 86-90.

[12] Amonum JI, Nyam RT, Gbande S (2016) Effect of pretreatments on seed germination of Parkia biglobosa (Benth). Journal of Research in Forestery, Wildlife and Environment 8 (4) : 364-369.

[13] Assogbadjo AE, Kyndt T, Sinsin B, Gheysen G, Van Damme P (2006) Patterns of genetic and morphometric diversity in baobab (Adansonia digitata L.) populations across different climatic zones of Benin (West Africa). Annals of Botany, 97 : 819-830.

[14] Assogbadjo AE, Sinsin B, Codjia JTC, Van Damme P (2005) Ecological diversity and pulp, seed and kernel production of the baobab (Adansonia digitata) in Benin. Belgian Journal of Botany. 138(1) : 4756.

[15] Bakayoko A, Khatelain C, Kone MW, Kone I, Ouattara D, Yao K, Gautier L (2020) Occurrences des échantillons de plantes de l'Herbier du Centre Suisse de Recherches Scientifiques (CSRS) en Côte d'Ivoire. Version 1.2. Centre Suisse de Recherches Scientifiques en Côte d'Ivoire. Occurrence dataset https://doi.org/10.15468/gdbrsj Ajouter au projet Citavi par DOI accessed via GBIF.org on 2021-0305 .

[16] Barry AA, Caesar J, Tank AMGK, Aguilar E, McSweeney C, Cyrille AM, Nikiema MP, Narcisse KB, Sima F, Stafford G, Touray LM, Ayilari-Naa JA, Mendes CL, Tounkara M, Gar-Glahn EVS, Coulibaly MS, Dieh MF, Mouhaimouni M, Oyegade JA, Sambou E, Laogbessi ET (2018). West Africa climate extremes and climate change indices. Int. J. Climatol. 38, e921-e938. https://doi.org/10.1002/joc.5420.

[17] Berka S, Abdelkader H (2001) Effets de quelques traitements physico-chimiques et de la température sur la faculté germinative de la graine d'Arganier. Revue Forestière Française 53 (2) :125-130.

[18] Bornand M, Barthès JP, Bonfils P (1999) Carte des pédopaysage de la région languédoc-RoussillonDépartement de l'Hérault. INRA Montpellier 2010. 2p

[19] Choat B, Jansen S, Brodribb TJ, Cochard H, Delzon S, Bhaskar R, Bucci SJ, Feild TS, Gleason SM, Hacke UG, Jacobsen AL, Lens F, Maherali H, Martinez-Vilalta J, Mayr S, Mencuccini M, Mitchell PJ, Nardini A, Pittermann J, Pratt RB, Sperry JS, Westoby M, Wright IJ, Zanne AE (2012) Global convergence in the vulnerability of forests to drought. Nature (491) : 752-755. doi:10.1038/nature11688
[20] CITES Secrétariat (2016) Notification of the Parties No. 2016/008. https://cites.org/sites/default/files/notif/E Notif 2016 008.pdf

[21] CoP17 Prop. 57 (2016) Convention sur le commerce international des espèces de faune et de flore sauvages menacées d'extinction. " dix-septième session de la conférence des parties Johannesburg (Afrique du sud); 24 septembre 5 octobre 2016: examen des propositions d'amendement des annexes I et II ». 17 p.

[22] Dianda M, Bayala J, Diop T, Ouédraogo SJ (2009) Improving growth of shea butter tree (Vitellaria paradoxa C.F.Gaertn.) seedlings using mineral N, P and arbuscular mycorrhizal (AM) fungi. Biotechnol. Agron. Soc. Environ., 13(1) : 93-102.

[23] Dianda M, Chalifour FP (2002) Effets du N minéral et du génotype de la plante sur la croissance et la nodulation de Faidherbia albida. Can. J. Bot., 80(3) : 241-254.

[24] Diatta S, Salifou I, Sy Mo, Kabore-Zoungrana CY, Banoin M, Akpo LE (2009) Évaluation des potentialités germinatives d'un ligneux fourrager sahélien : Maerua crassifolia Forssk., Capparaceae. 1-11p http://www.irrd.org

[25] Dipelet UGB, Doumenge C, Loumeto JL, Jacques F, Gonmadje C, Doyle M (2019) Des confusions entre espèces préjudiciables à la gestion durable des essences forestières : l'exemple des acajous d'Afrique (Khaya, Meliaceae). Bois et forêts des tropiques 339 (1) : p 17-32.

[26] Djaha JA, N'da AAA, Koffi EK, Ballo CK, Coulibaly M (2012) Croissance et aptitude au greffage de deux génotypes d'anacardier (Anacardium occidentale L.) élites utilisées comme porte-greffe en Côte d'Ivoire. Int. J. Biol. Chem. Sci. 6(4) : 1453-1466, August 2012 14p. http://ajol.info/index.php/ijbcs. DOI http://dx.doi.org/10.4314/ijbcs.v6i4.5

[27] Douma S, Adamou MM, Aboubacar K, Alleidi I, Boubacar AN (2019) Effet du régime d'irrigation sur la germination et la croissance en pépinière de Parkia biglobosa (Jacq.) G. Don. J.Anim.Plant Sci, 40 (1) : 6573-6583. http://www.m.elewa.org/JAPS ; ISSN 2071-7024

[28] Dumenu WK (2019) Assessing the impact of felling/export ban and CITES designation on exploitation of African rosewood (Pterocarpus erinaceus). Biological Conservation 236 (2019) 124-133. https://doi.org/10.1016/j.biocon.2019.05.044

[29] FAO (2005) State of the World's Forests disponible sur http://www.fao.org/3/a-y5574e.pdf.

[30] Giordano E (1972) Interaction de la sélection et de la culture intensive. Unasylva, 97- $98: 82-88$.

[31] Gnanglè PCR, Glele K, Oumorou M, N'djolosse K, Bonou W, Sokpon N (2010) Tests de croissance de jeunes plants de néré (Parkia biglobosa, Jack, R. Br.) en pépinière. Int. J. Biol. Chem. Sci. 4(6) : 1939-1952

[32] Goba AE, Koffi G, Raoul SS, Leonie C K, Yeboa AK (2019) Structure démographique et régénération naturelle des peuplements naturelle de Pterocarpus erinaceus Poir. (Fabaceae) des savanes de Côte d'Ivoire. Bois et forêt des Tropiques, $341(3): 5-14$

[33] Gorgon IT, Olga DY, Komla EA, Francois W, Kouami K (2015) Essai de germination et de croissance au stade 
juvénile des souches locales de Jatropha curcas en république centre africaine. European Scientific Journal ; vol.11, No.15. 260-276.

[34] Goula BT, Brou K, Brou T, Savane I, Vamoryba F, Bernard S (2007) Estimation des pluies exceptionnelles journalières en zone tropicale : cas de la Côte d'Ivoire par comparaison des lois Log normale et de Gumbel. Journal des Sciences Hydrologiques. 52 (1) : 49-67.

[35] Guillaumet JL, Adjanohoun E, Avenard J M, Eldin M, Girard G, Circoulin J, Toucheboeuf P, Perraud A (1971) Le milieu naturel de Côte d'Ivoire. Mém.ORSTOM no50. ORSTOM, Paris. Pp156-264.

[36] Hérault B, N'guessan AK, Ouatara N, Ahoba A, Bénédet F, Coulibaly B, Doua-bi Y, Koffi T, Koffi-Konan JC, Konaté I, Tieoulé F, Wourro F, Zo-Bi IC, Louppe D (2020) The long-term performance of 35 tree species of sudanian West Africa in pure and mixed plantings. Forest Ecology and $\begin{array}{lll}\text { Management } & 468 & \text { (2020) }\end{array}$ https://doi.org/10.1016/j.foreco.2020.118171

[37] Houndonougbo JSH, Kassa B, Mensah S, Salako VK, Glèlè Kakaï R, Assogbadjo AE (2020) A global systematic review on conservation nd domestication of Parkia biglobosa (Jacq.) R. Br. ex G. Don, an indigenous fruit tree species in SubSahara African traditional parklands: current knowledge and future directions. Genet Resour Crop Evol (2020) 67:10511066. https://doi.org/10.1007/s10722-020-00892-w

[38] Koffi KJ, Kouassi AF, Ake-assi AE, Yao K, N'goran KSB, N'Goran B (2018) Liste de quelques espèces à statuts particuliers de l'herbier du Centre National de Floristique (CNF) en Côte d'Ivoire. Version 1.2. Centre National de Floristique. Occurrence dataset https://doi.org/10.15468/ckbuue Ajouter au projet Citavi par DOI accessed via GBIF.org on 2021-03-05.

[39] Kossi NS, Kossi A, Abdou RR, Adzo DK, Kouami K, Rabiou H, Pouwisawe K, Babou AB, Ali M (2015) Importance socio-economique de pterocarpus erinaceus poir. au Togo. European Scientific Journal, $\mathrm{N}^{\circ} 23$ (11) : p 135-145

[40] Laurie, M. V., 1974. Tree planting practices in African savannas. Food and Agriculture Organization of the United Nations, Rome. pp. 42-43.

[41] Leroy M, Derroire G, Vendé J, Leménager T (2015) La gestion durable des forêts tropicales. De l'analyse critique du concept à l'évaluation environnementale des dispositifs de gestion. Bois et forêts des tropiques, $\mathrm{N}^{\circ} 325$ (3) : p 86-87.

[42] Louppe D, Ouattara N (1996) Les arboretums d'espèces locales en Nord Côte d'Ivoire. IDEFOR.

[43] Mabetty T (2018) Le néré, un arbre du patrimoine de la Haute Guinée. Belgeo, 2. 24p, consulté le 3 avril 2020. URL : http://journals.openedition.org/belgeo/21569

[44] Maranz S, Wiesman Z (2003) Evidence for indigenous selection and distribution of the shea tree, Vitellaria paradoxa, and its potential significance to prevailing parkland savanna tree patterns in sub- Saharan Africa north of the equator. J. Biogeogr., 30: 1505-1516.

[45] Mbowa C, Chhinb S, Samboua B, Skolec D (2013) Potential of dendrochronology to assess annual rates of biomass productivity in savanna trees of West Africa.
Dendrochronologia $\quad 31 \quad$ : $\quad 41-\quad 51$. http://dx.doi.org/10.1016/j.dendro.2012.06.001

[46] Millan M (2016). Analyse de la variabilité des traits architecturaux des formes de croissance dans les communautés végétales. Thèse de Botanique. Université de Montpellier. Français. 178 p. https://tel.archivesouvertes.fr/tel-02489116

[47] MINEF (2013) Décret n 2013-508 du 25 juillet 2013portant interdiction de l'exploitation, de la coupe, du transport, de la commercialisation et de l'exportation de Pterocarpus spp appelé communément «bois de vêne ». Journal Officiel de la République de Côte d'Ivoire, 22 août 2013. pp 532-533.

[48] Nations Unies (2002) Rapport du Sommet mondial pour le développement durable. Johannesburg (Afrique du Sud) 26 aout-4 septembre 2002. 191p.

[49] N'golo B, Noufou DO, Djézou K, Adama B, Fezan H T (2018) Effets de cinq prétraitements sur la germination du vène (Pterocarpus erinaceus Poir., Fabaceae) dans la Réserve du Haut Bandama (Côte d'Ivoire). European Scientific Journal, 30 (14) : p 438-453

[50] Ouedraogo A, Adjima T, Hahn-Hadjali K, Guinko S (2006) Diagnostic de l'état de dégradation des peuplements de quatre espèces ligneuses en zone soudanienne du Burkina Faso. Sécheresse, 17 (4) : p 485-491

[51] Perraud A (1971) Les sols. In : Le milieu naturel de la Côte d'Ivoire. Mémoires ORSTOM $50:$ 69-390.

[52] Rabiou H, Adjonou K, Issaharou-matchi I, Segla KN, Bationo BA, Kohutse AD, Mahamane A, Kokou K (2019) Influence of anthropogenic and ecological factors on stand structure of Pterocarpus erinaceus Poir. in Sudanian and Sahelian zones of Burkina Faso and Niger. J. Ecol. Nat. Environ. Vol. 11(7), pp. 98-107. DOI: 10.5897/JENE2019.0776

[53] Rabiou H, Segla KN, Adjonou K, Radji AR, Moussa MB, Saley K, Kokutse AD, Bationo BA, Mahamane A, Kokou K (2015) Estimate trees potential and wood cubage in natural stands of Pterocarpus erinaceus Poir. based on ecological gradient in West Africa. Int.J.Curr.Microbiol.App.Sci (2015) 4(5): 1103-1117

[54] Rabiou H, Diouf A, Bationo AB, Segla NK, Adjonou K, Kokutse DA, Radji R, Kokou K, Mahamane A, Saadou M (2015) Structure des peuplements naturels de Pterocarpus erinaceus Poir.dans le domaine soudanien, au Niger et au Burkina Faso. Bois et forêts des tropiques 325 (3) : p 71-125.

[55] Rajendrudu G, Naidu CV (2001) Influence of kinetin and nitrogenous salts on seed germination of red sanders (Pterocarpus santalinus Linn. f.). Seed Science and Technology 29 (3) : 669-672.

[56] REDD+ (2017) « Stratégie nationale Redd+, Côte d'Ivoire » 15p. https://chm.cbd.int/api/v2017/documents/

[57] Salazar R, Quesada M (1987) Provenance variation in Guazuma ulmifolia L. in Costa Rica. Commonwealth Forestry Review, 66: 317-324.

[58] Sambe M, Sagna M, Sy MO (2010) Seed germination and in vitro plant regeneration of Parkia biglobosa (Jacq.) Benth. African Journal of Biotechnology, 9(21): 3099-3108.

[59] Segla KN, Adjonou K, Rabiou H, Bationo BA, Mahamane A, Guibal D, Kokou K, Chaix G, Kokutse AD, Langbour P 
(2020) Relations between the ecological conditions and the properties of Pterocarpus erinaceus Poir. wood from the Guinean-Sudanian and Sahelian zones of West Africa. Holzforschung aop. 11 p. https://doi.org/10.1515/hf-20190250

[60] Segla NK, Rabiou H, Adjonou K, Moussa BM, Saley K, Radji RA, Kokutse AD, Bationo AB, Mahamane A, Kokou $\mathrm{K}$ (2016) Population structure and minimum felling diameter of Pterocarpus erinaceus Poir in arid and semi-arid climate zones of West Africa. South African Journal of Botany 103 (2016) 17-24. http://dx.doi.org/10.1016/j.sajb.2015.09.005

[61] Soloviev P, Niang TD, Gaye A, Totte A (2004) Variabilité des caractères physicochimiques des fruits de trois espèces ligneuses de cueillette, récoltés au Sénégal : Adansonia digitata, Balanites aegyptiaca et Tamarindus indica. Fruits, $59: 109-119$.

[62] Soro GE (2011) Modélisation statistique des pluies extrêmes en Côte d'Ivoire. Thèse unique. Abidjan (Côte d'Ivoire) : Université Nangui Abrogoua. $173 \mathrm{p}$

[63] Zerbo P, Belem B, Mllogo-Rasolodimby J, Van Damme P (2010) Germination sexuée et croissance précoce d'Ozoroainsignis Del., une espèce médicinale du Burkina Faso. Cameroon Journal of Experimental Biology 2010 Vol. $06 \mathrm{~N}^{\circ} 02,74-80$. 